\title{
Implementation of Supply Chain Management and its Effectiveness on Marketing of Business Organisations
}

\author{
Prof. Rekha D. M1, Sowmya A V \\ ${ }^{1}$ Assistant Professor, Department of Commerce, ${ }^{2}$ Student \\ ${ }_{1,2}$ SJR PU College for Women, Bangalore, Karnataka, India
}

\begin{abstract}
How to cite this paper: Prof. Rekha D. M I Sowmya A V "Implementation of Supply Chain Management and its Effectiveness on Marketing of Business Organisations" Published in International Journal of Trend in Scientific Research and Development (ijtsrd), ISSN: 24566470, Volume-3 | Issue-4, June 2019, pp.777-779, URL: https://www.ijtsrd.c om/papers/ijtsrd23 876.pdf

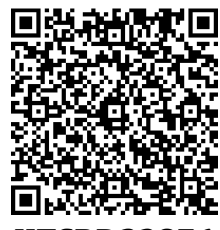
IITSRD23876
\end{abstract}

Copyright (C) 2019 by author(s) and International Journal of Trend in Scientific Research and Development Journal. This is an Open Access article distributed under the terms of the Creative Commons

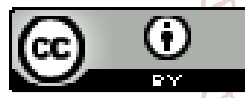
Attribution License (CC BY 4.0) (http://creativecommons.org/licenses/ by $/ 4.0$ )

There are hundreds of way goods and services can be distributed no single distribution satisfied the needs of every firm so different channels are used to reach different market segment. Supply chain management is an art of management of flow of materials and products from the source of production to the end user. This system includes the total flow material right from the stage of raw materials to the delivery of finished product to the customer. Supply chain management is another aspect of advanced planning and scheduling.

There are two types in supply chain management, one is traditional supply chain channel and the manufacture, wholesaler, retailer have to build up a chain of facilitating services so as ensure that the right product reaches the final consumer. Here, the manufacture was dependent on the intermediaries to offer qualitative service throughout the chain, maintain low costs and the deliver goods and services to customer. Another supply chain channel is the 'Limited channel', when retailer works directly with the producer and can therefore eliminate wholesaler and the exact cost involved in this part of the chain. There are certain retailer's viveks, Durian furniture and so on that deal directly with supplier and create limited supply chains. Another supply chain alternative is the direct channel, where the product or service is directly sold by the producer or retailer like the
Raymond's stores, club resorts. Here by using different direct sales promotion techniques, such as direct mailing or internet (online) services or telemarketing and so on the channel is kept direct and extra charges and commission are just eliminated.

Irrespective of the type of channel flow, apart from the flow of physical goods, there are other type of flow for supply chain to be successful. these could be: physical flow, ownership flow, service flow, information flow, payment flow, and promotion flow, Irrespective of which method of distribution is used, good logistic and supply chain management techniques have to be used to ensure the smooth movement of merchandise till it reaches the hand of the consumers.

Supply chain control is channel are the organized shape of client and sellers supply chain management is an artwork of control for drift the materials, and products from the supply of production to the quit person .supply chain management is an essential a part of each company whether or not small are huge organisation. SCM is the achieve management of supply chain sports to maximise the patron value and achieve a sustainable competitive gain. TheSCM includes gear are modules used to execute supply chain transactions, control suppliers relationships and manipulate associated business manner. 
REVIEW OF LITERETURE:

Iyatullah, RnaakeshNarain, Amar Singh (2015) conducted research study which was aimed to provide insight into the similarities and dissimilarities of supply chain management practices between large enterprises and small and medium enterprises of India. Study found that despite of so many constraints, the managers of the SMEs need to bring in a cultural change in their attitude needed to outlive and outperform other firms existing at every tier of supply chains of LEs. If only SMEs could focus on better strategic planning and management of their businesses and not just only on economic aspects, they could reap much more dividends.

Kiran Bala (2014) conducted a study which was aimed to understand what supply chain management is and how it is affecting organization, what are different challenges and it can be proved as a tool for improving overall performance in today's global competitive environment. They concluded that assessing supply chain performance leads to identification of problems and opportunities, having a strategy and measuring key parts are necessary to understand and take control of supply chain.

T.N Varma,D.A Khan(2014) studied use of information technology in supply chain management in which he discusses the role of IT as an enabler in supply chain management with vast benefits to organizations with a comprehensive IT implementation as well as curbing e-risks.

Wong, Lai \& Cheng (2011-12) in their study on Value of Information Integration to Supply Chain Management, under what circumstances does information integration contribute to better performance outcomes in supply chain management (SCM). The study provides managers with empirical insights on the effects of information integration on the cost and customer-oriented operational performance of SCM under favourable and unfavourable environmental conditions.

V. M Rao Tummala,TobiasSchoenherr(2008) conducted study which aims to facilitate the task by developing an implementation decision framework for SCM initiatives based on best practices and reveals the framework consists of SCM goals, enablers, SCM initiatives and the defining operational activities which will enable firms to develop and implement SCM plans logically and in systematic fashion. Furthermore the framework can be used with analytic hierarchy process modeling process to systematically prioritize the SCM plans for effective implementation by companies.

According to Thatte, (2007) the sub-constructs for supply chain responsiveness includes operation system responsiveness, logistic process responsiveness and supplier network responsiveness. Operation system responsiveness is the ability of firm's manufacturing system to address changes in customers demand. It includes both manufacturing and service operations.

Jonathan D linton ,et.al.,(2007)-Sustainable supply chains an introduction-journal of operations management25(6), 1075-1082,2007 - The focus on environmental management and operation is moved from local optimisation of environmental factors to consideration of the entire supply chain during the production, consumption, customer service and post disposal disposition of product.
Responsiveness is the ability of firm's manufacturing system to address changes in customer demand. Its includes both manufacturing and service operation.

Angerhofer\& Angelides (2006): discuss levels of collaboration that could be undertaken in a supply chain: strategic, managerial, and operational. The researcher collaborates at the operational level in transportation scheduling. By working with retailers, suppliers could improve delivery performance through sharing of stock levels. Collaboration at the managerial level could result in better planning and increased forecast accuracy. At the strategic level, collaboration could result in capital investment to improve the supply chain. The author has discussed the supply chain only through levels and has concentrated on levels of stock and capital investment as major criteria. The researcher 85 analyses that only cost or financial performances are not the vital element constituting the supply chain performance.

Kim, Chatfield, Harrison \&Hayya (2006), suggests a set of best organization structures for efficient supply chain management. It derives organization types for supply chain management according to the formalization and centralization level of an independent department responsible for supply chain management (SCM) activities, and hierarchical relationship in organizational position and operational responsibility between the SCM department and other functional departments. the SCM department maintains an adequate level of balance and harmony with other functional departments.

Sengupta, Kaushik (2006), supply chain research focuses exclusively on the manufacturing sector. To address the deficiency, this research article compares the effect of traditional manufacturing-oriented supply chain strategies on the operational and financial performance of firms in both service and manufacturing sectors. This study defines organizational performance through operational results and financial results as measured by the respondents' perceived performance. Financial performance is measured by the company's relative cost and profit-related performance compared with its direct competitors.

Chen and Paulraj (2004):Supply chain management is not only limited to logistics activities and planning and control of materials and information flow internally within the company or externally between companies. It also deals with the strategic decisions such as inter-organizational issues, alternative organizational form to vertical integration. It is also the management of relationship between suppliers and customers.

Ulf Paulsson(2004): supply chain risk management-journal of supply chain risk,79-96,2004-The chin of transport and storage activates from first supplier to end customer has during $g$ the years changed character and gradually developed, from a stepwise chain via a logistical chain into a supply chain the number and charter of the risk and the total risk exposure changes as the chain changes.

\section{ANALYSIS}

$>$ Organisational performance evaluation can be done through proper implementation of supply chain management practices ,in the study also it represents 
that performance evaluation can be easily focus supply chain practices based on good relationship with suppliers company can also focus on its brand image customers loyalty towards organisational products and services.

$>$ Effective supply chain leads to good relationship with customers. Which always helps in maintaining high quality production and services, this also in turn it also helps to balance the demand and supply in market. Since there is good relationship company and customers, company can focus on its requirements.

$>$ Organisation policy leads to proper improvement of the supply chain process therefore organisation policy should be in favour of implementing with it advance technology. Has it helps to smooth flow of operations.

$>$ Operationally it is proved that proper supply chain strategy will always increase sales and it leads to better growth. Which also have a better working condition in supply chain management logistics, Which focus on expansion distribution channel and also helps in proper decision making.

\section{CONCLUSION}

Supply chain management is very important for every organisation to maximize customer loyalty and to achieve competitive advantage. It is very important are an organisation to implement process are sequence in distribute goods and services ultimate users.

Companies' capability and profitability through proper channel like supply chain always lead to companies' growth. Supply chain management can lower operational expenses with proper planning from manufacturering to transportation. Since it is back bone of organisation which manages critical issues and also leads to growth of organisation through competitive advantage and increase of customers.

\section{REFERNCES:}

[1] Handfield R. B. and Nichols E. L., "Introduction to Supply Chain Management", Prentice-Hall, New Jersey, 1999,pp. 1-183. Jüttner U., Christopher M. and Baker S., "Demand chain management-integrating marketing and supply chain management", Industrial Marketing Management, (36: 3). 2007.
[2] Sandelands E. "Building Supply Chain Relationships," International Journal of Physical Distribution and Logistics Management, (24: 3), 1994, pp. 43-44. Sanders N. R., Locke A., Moore C. B. and Autry C. W., "A Multidimensional Framework for Understanding Outsourcing Arrangements", The Journal of Supply Chain Management, (43: 4), 2007.

[3] Scott C. and Westbrook R., "New Strategic Tools for Supply Chain Management, "International Journal of Physical Distribution \& Logistics Management, (21: 1), 1991, pp. Hunt, S. D., \& Davis, D. F. (2008). Grounding supply chain management in resourceadvantage theory. Journal of Supply Chain Management,44(1), 10-21

[4] Wisner J. D. And K. C. Tan. "Supply Chain Management and Its Impact on Purchasing," The Journal of Supply Chain Management, (36: 4), 2000, pp. 33-42.

[5] D. Power, "Supply chain management integration and implementation: a literature review," Supply Chain Management: An International Journal, vol. 10, no. 4, pp. 252-263, 2005.

[6] D. Twigg, "Managing product development within a design chain," International Journal of Operations \& Production Management, vol. 18, no. 5, pp. 508-24, 1998.

[7] R. B. Handfield, G. L Ragatz, K. J. Petersen, and R. M. Monczka, "Involving suppliers in new product development," California Management Review, vol. 42, no. 1, pp. 59-82, 1999.

[8] D. C. Juran and H. Dershin, "Lessons in supply chain assessment and improvement," Quality Focus, vol. 4, no. 1, pp. 18-27, 2000. [46] D. F. Ross, Competing Through Supply Chain Management, Chapman \& Hall, New York, N.Y,1998.

[9] Logistics and Supply Chain Management by Martin Christopher

[10] Supply Chain Management: Strategy, Planning, and Operation by Sunil Chopra

[11] text books relating to Bangalore university 